\title{
RECENT DEVELOPMENTS IN THE LAW OF CONTRACTS
}

HERE is only one way to record accurately the progress of
any branch of the law over a period of time; that is to review all of the cases and statutes affecting it that have been litigated or enacted during the period. This includes all of the cases in the minor courts as well as those in the courts of appeal, unless we arbitrarily limit our subject matter to the work of the higher courts. It is not desirable to fix such a limit.

It would be quite possible also, and reasonable as well, to include in our review the work of arbitrators, executives, and administrative boards and commissions; for undoubtedly all these have some judicial and law-making functions. Having included all these, it would seem logical to go further and to record the practices and activities of individual men; for it is these that create and apply the mores on which what we call law is based and by which our progressive judicial action and legislation are determined.

From this it appears that a review of the progress of the law may be made to include every individual action of every individual man, woman, and child during the selected period. It is, indeed, this great multitude of individual actions and transactions of innumerable human beings that constitute life and human progress along the corridor of time. They form the basis and subject matter of all generalization, of all " laws" or rules of human action. Each statement of a "rule" of law is a generalization drawn from this seething, pulsing background of life. A report on the progress of the law, therefore, is a report on the changing generalizations required by the changes in this huge, amorphous background of action and transaction.

We are in the habit of thinking of these actions and transactions as being directed and determined by "rules". If this were wholly true, there would be no progress of the law to report. But the fact is that there are no absolute and antecedent rules, governing human action, that are known to man. The mighty river of actions and transactions determines and changes its own banks. 
This constitutes an evolution, a progress, of man and his "law" that can be reviewed and restated.

It must not be inferred from this that there are no rules or principles, no "law", that can be stated and reviewed. There is a river of life that flows, that maintains a reasonably consistent course. It can be traced and described. Useful and reasonably accurate generalizations can be made that record the past course of the stream and that forecast, with a good degree of dependability, its course in the future. But the forecast must always fail in some degree. The stream meanders; and the future varies from the past. It is this meandering, this variation, that is presented by a review of the progress of the law. The fact that the forecast fails at the points of change does not show that forecasts are always false and misleading. On the contrary, they constitute our only guide. They are the light of experience and the sole basis of wisdom. The generalizations that we draw are the working rules by which we live. It is these "working rules" that constitute the whole of our law. Never wholly accurate and dependable, they are nevertheless the guides by which the judge makes decisions and the lawyer gives advice. A review of the progress of the law is a review of these working rules.

There is a vast difference in the soundness and accuracy of the generalizations, the major premises, articulate or inarticulate, that judges make and use in the process of decision and that lawyers use in advising a client. This means no more than that there is a vast difference in judges and in lawyers and law writers, in their intellectual power, their knowledge of the living stream, their experience in human life. Some accept generalizations of others, at secondhand or thirdhand or worse, generalizations of men even weaker than themselves. Others decide and advise by instinct and "hunch", their generalizations being mainly inarticulate, or even subconscious. Here, as in all other fields of life, it pays to employ the best and the rarest, the man who knows books but also knows their limitations, the man who has accumulated an understanding experience but realizes how incomplete that experience must be, the man who may advise upon a "hunch" but whose hunches are based upon his own actual experience in life and upon the recorded experience of others.

There have indeed been changes in the stated rules of law in 
the field of contracts in the last fifty years; that is to say, there are differences between the generalizations that were formerly drawn and those that must now be drawn from the judicial decisions and business practices and human customs of the period. There will be similar, and perhaps more extensive, changes in the next fifty years. The past seems not wholly to determine the future; or, if it does, no jurist or adviser is capable of knowing all of the elements of the past that are influential in determining the future. This is the reason that we can never attain that "paradise of justice", that "solid land of fixed and certain rules", of which Judge, later Mr. Justice, Cardozo wrote in I92 I in The Nature of the Judicial Process. This is why the law must forever continue to be stated and restated, becoming in the process ever more complex and more difficult of mastery by a student or a judge. This is why the American Law Institute's Restatement of the Law of Contracts does not contain the last, the perfect, and the unchangeable word and rule and principle. If any reporter or adviser or member of the Institute has thought otherwise, he must be included among the blind who attempt to lead the blind. That Restatement does not crystallize or embalm the living law so that it shall be thereafter dead. It is merely a new statement of what a number of men, of some degree of expertness, think is now the proper generalization to be drawn from the past and used to predict and to influence the future.

This "Restatement" is perhaps the best evidence of some of the more important changes in the law of the last fifty years. At all events, it may be useful to call attention here to some of the changes that the Restatement indicates, changes that must be evident to any student who carefully compares it with the previous treatises and articles of law writers, even of those very writers who composed the committee that constructed the Restatement.

\section{IRREVOCABLE OFFERS}

Prior to fifty years ago, it was often said that all offers must of necessity remain revocable at the will of the offeror until an effective acceptance is made. "An irrevocable offer is a legal impossibility." But it has been discovered that "impossible" is a large word, the applicability of which is constantly decreasing. 
The older view was dependent on the idea that all contracts are expressions of the will of the parties and that the will is not subject to judicial control. Carried to its logical conclusion, this idea would equally result in a rule that each of the parties would have control of the obligation after acceptance as well as before. The truth is that it is the will of others, not the will of the contractors, that determines the legal relations that are consequent upon all the facts of life, including our voluntary expressions of assent. Others may not be able to control my will; but they can control my action, and the processes of enforcement are not at all dependent upon the state of my mind. Therefore, since enforcement has always been granted, in spite of a change of mind by the offeror that takes place after acceptance, it can be granted with equal effectiveness in spite of his change of mind before any acceptance. Whether such enforcement should or should not be made available is a mere question of social policy, determined as in the case of all other rules of law by the mores of the community - by notions of practical convenience and by business practice and custom.

The Restatement recognizes at least three sets of circumstances under which an offer may be irrevocable. An offer that makes acceptance consist of non-promissory action, the resulting contract to be described as " unilateral", is declared in Section 45 to become in itself a contract as soon as the requested action is "given or tendered". Such contract, however, is further declared to be "conditional on the full consideration being given or tendered within the time stated in the offer, or, if no time is stated therein, within a reasonable time". The meaning and effect of this are in no way different from those of a rule stating that the offer shall be irrevocable after the requested action is begun or tendered. The beginning of action by the offeree deprives the offeror of his power to revoke, making his expression of a change of mind quite inoperative to prevent enforcement. The offeree's power to accept is a continuing power, in spite of a notice of revocation.

Likewise, under Section 46 , an offer " cannot be terminated" if the promise contained in it has been made binding by a seal or a consideration, even though the duty created thereby is still conditional upon an expression of acceptance by the other party. This is merely what is commonly called a "binding option ". It creates an irrevocable power in the offeree. And, thirdly, under Section 
47 , an offer is made irrevocable if the offeror has made a " collateral contract " not to revoke it.

These rules represent a definite evolution in the popular and the judicial notions as to offers - a development of new law. As worded by the Institute, there is no doubt that they leave openings for a conflict of interpretation and application. So do all other rules, however worded or by whomsoever stated or enacted. They do not and cannot prevent further evolution and development, just as in the past. Further, it goes without saying that courts can repudiate them outright, if they feel so inclined; but they will not feel so inclined if the rule as stated is substantially in harmony with common practice and prevailing mores.

\section{The Consideration Doctrine}

In the courts, the doctrine of consideration has gone its accustomed course. This course has involved an assumption that the term consideration has a simple and uniformly applied definition, that such a consideration is indispensable to the enforcement of any informal promise, and that the court's only function is one of deductive reasoning. The assumption has always been false; the existence of consideration as defined by anybody has never been totally indispensable; and the principal function of the courts is not deductive, but is, instead, the determination of whether or not there is good reason for enforcing the promise sued on - a question of social policy.

The American Law Institute chose to adopt a definition of consideration that is markedly narrower than the prevailing usage of the term by courts and people in general. ${ }^{1}$ By the chosen definition, consideration for a promise is something that is bargained for and given in exchange for the promise. This "something" is, indeed, very liberally defined. It is no longer required to be given by the promisee, but may be given by a third party. It is no longer required to be a " detriment to the promisee" or a "benefit to the promisor". Instead, it is declared that "gain or advantage to the promisor or loss or disadvantage to the promisee ... do not affect the sufficiency of consideration ". 2 It may be an act, a forbearance, a promise, or any change in legal relations; but in any

I See Restatearent, Contracts (I932) \$ 75 .

2 Id. $\$ 8 \mathrm{r}$. 
case it must be "bargained for and given in exchange for the promise". Such a definition as this excludes all "past considerations", all merely moral obligations that some preëxisting transaction has created, and also many subsequent actions by the promisee in reliance on the promise.

This shows clearly enough that the definition, although much like that of Mr. Justice Holmes, ${ }^{3}$ is not in accord with the common usage of courts. According to judicial opinions, there are many past transactions, never bargained for by the promisor, that are sufficient to make his promise binding. Also, there are very many cases that hold that a promise may become binding by reason of action by the promisee in reliance on the promise, even though such action was never bargained for by the promisor. Also, in a considerable number of states, a preëxisting moral obligation is a sufficient reason for the enforcement of a subsequent promise to perform it. All of these various reasons for enforcing the promise are almost universally called " consideration" and are held to be sufficient to make the promise binding.

The fact is that the function of the courts is not to create a definition and a rule and then to apply them mechanically and dogmatically by a process of severe deductive logic; instead, it is to determine whether a sound and sufficient reason exists for the enforcement of the promise. When the court finds such a reason, it cheerfully calls it a sufficient consideration. The real question for the courts is what promises shall be enforced, not what is a sufficient consideration. The Law Institute recognized that it must state rules that would show what promises are enforceable even though there is no consideration as narrowly defined in the Restatement. The result is that there are ten sections under the topical heading "Informal Contracts without Assent or Consideration ". To the present writer, it seems certain that these ten sections fail to include several sorts of cases in which the courts are finding sufficient reason for enforcing an informal promise. In a goodly number of States, including such populous ones as New York and Pennsylvania, it has been held that a preëxisting moral obligation (or a previous action creating such a moral obli-

3 See Wisconsin \& Mich. Ry. v. Powers, Igr U. S. 379, 386 (I903); Martin v. Meles, I79 Mass. II4, 60 N. E. 397 (IgOr). 
gation) is a sufficient consideration for a promise to perform it. ${ }^{4}$ It may well be that the Institute was correct in refusing to state a rule in accord with these decisions. There is more difficulty in defining moral obligation than in defining consideration; and the decisions do not enable us to determine what kind and degree of moral obligation it takes to make a promise legally enforceable. At the same time, those decisions contrary to the Restatement rule cannot safely be ignored by the lawyers of other states, where a court may at any time adopt the doctrine and hold that a preëxisting moral obligation is a sufficient reason for enforcing a promise to perform it, whether it is called a "consideration" or not.

Originally, the policy of the Institute in narrowing the definition of consideration to a bargained-for exchange seemed unsound. It certainly will be difficult to induce judicial tongues and pens to adhere to it. But further thought leads to approval of the definition, when it is accompanied by the definite assertion that many informal promises are enforceable without any consideration at all. This tends to free the judicial mind from the shackles of mere deductive logic and directs attention to the much more important judicial function of determining sound policy on the basis of mores and prevailing custom. The occasional maverick whom this leads to think that he is wiser than the past and can determine justice at his own free will can safely be disregarded. The mores are more flexible than is deductive logic; but their eventual resistance overcomes even a revolution. This logic never did.

Among the informal promises that are declared by the Institute to be binding without any consideration are those covered by Section 90 of the Restatement. This reads as follows: "A promise which the promisor should reasonably expect to induce action or

4 See the recent case of Webb v. McGowin, I68 So. 196, I99 (Ala. I936), in which both the Court of Appeals and the Supreme Court of Alabama found a sufficient consideration and enforced the promise. The plaintiff had sacrificed himself, at the cost of an injury resulting in total disability, in order to save the defendant's testator from death. In recognition of a moral obligation, the testator promised to pay to the plaintiff the sum of $\$ 15$ every two weeks during the remainder of his life. The testator's executor was held bound to continue the payment. The moving reason was that there had been a substantial benefit to the person of the promisor. The court excluded moral obligations that are solely "based upon some refined sense of ethical duty without material benefit" to the promisor. Id. at 199. See also Medberry v. Olcovich, 60 P.(2d) 28I (Cal. 1936), aff'g 59 P.(2d) 55 I (Cal. I936). 
forbearance of a definite and substantial character on the part of the promisee and which does induce such action or forbearance is binding if injustice can be avoided only by enforcement of the promise." At the meeting of the Institute at which this section was presented, attacks upon it were made by several members. Nevertheless, it was approved by a very large majority. The objectors were chiefly law teachers who had been taught a different rule when they were law school students and who were continuing to teach others as they themselves had been taught. The present writer believes that the rule is substantially in harmony with judicial decisions going back to the very origin of the action of assumpsit. If this belief is correct, the rule is not a new development. But its statement in the present form is not in harmony with the supposed rule that all informal promises require consideration. That it is in harmony with very many actual decisions and with the instinctive reactions of the judges is indicated by the readiness with which the courts have already seized upon the section and used it as the major premise of their decisions in recent cases. ${ }^{5}$

It has long been supposed that the performance of an already existing legal duty is not a sufficient consideration for a promise, even though it is bargained for by the promisor and is actually given as the agreed exchange for the promise. Treatises on contracts so stated the rule and declared it to be applicable even in cases where the existing duty was a duty to some third person other than the promisor. The rule was supposed to be in harmony with prevailing notions of social policy. It may, therefore, come as a surprise that the Institute declares in Section 84 that "Consideration is not insufficient because of the fact ... (d) that the party giving the consideration is then bound by a contractual or a quasi-contractual duty to a third person to perform the act or forbearance given or promised as consideration ...." But there were some decisions, even prior to fifty years ago, that were in

5 E.g., Callan v. Andrews, 48 F.(2d) $x \times 8$ (C. C. A. 2d, 193I); Porter v. Commissioner, 6o F.(2d) 673 (C. C. A. 2d, 1932) ; James Baird Co. v. Gimbel Bros., 64 F.(2d) 344 (C. C. A. 2d, T933) (Restatearent cited and distinguished); Greiner v. Greiner, I3I Kan. 760, 293 Pac. 759 (I930); Anderson v. Truitt, I58 Md. I93, I48 Atl. 223 (I930); Lusk-Harbison-Jones, Inc. v. Universal Credit Co., I64 Miss. 693, I45 So. 623 (I933); Saunders v. Galbraith, 40 Ohio App. 155, $x 78$ N. E. 34 (r93 I); Union Trust Co. v. Long, 309 Pa. 470, r64 Atl. 346 (r932); Langer v. Superior Steel Corp., Io5 Pa. Super. 579, I6x Atl. 57x (I932). 
harmony with the rule stated in this section. Some modern decisions support it, although in some of them there is a specious attempt to reconcile the decision with the older rule. ${ }^{6}$ Here is an instance in which the authority of the Restatement may be enough to resolve the conflict in favor of the rule stated therein.

\section{Contracts Under Seal}

The sanctity of formal contracts under seal has to some degree been modified in recent years; but it is far from extinct. ${ }^{7}$ The effectiveness of sealing and delivery as one of several substitutes for consideration has long since ceased to be based upon the supposed solemnity of the transaction or upon vestiges of superstitious fear. Probably it now survives largely because it serves as a method by which a gratuitous promise can be made binding. However much we may be attached to the doctrine of consideration and there is no doubt that it serves a very useful purpose and expresses a nearly universal feeling - at the same time there is a desire that certain gratuitous promises shall be enforceable. Doubtless, the seal is a clumsy expedient, one that does not in itself select the good promises from the bad; but its long history gives it a workability that new devices do not have. In states that have abolished the common-law effect of a seal, there is some tendency to adopt legislation making written promises enforceable without any consideration. A uniform act to this effect has been proposed by the Commissioners on Uniform State Laws and has been adopted in Pennsylvania. ${ }^{8}$

6 E.g., Sasso v. K. G. \& G. Realty \& Const. Co., 98 Conn. 57I, I20 Atl. I58 (I923), (I923) 33 YaLE L. J. 78; Blakeslee v. Water Comm'rs, I06 Conn. 642, I39 Atl. I06 (I927). In these two cases, the court deals with a preëxisting contractual duty owed by the promisee to the promisor himself, not to a third party.

7 In Weil v. Poulsen, I2I Conn. 28I, I84 Atl. 580 (r936), the court held that under New York law a contract under seal cannot be modified by a subsequent contract not under seal, so long as the latter contract remains entirely executory. The American Law Institute states the contrary as the generally existing law. See Restatement, Contracts (1932) $\S 407$, comment c. The New York legislature passed an act in I 935 which seems to have the purpose of making fully effective an unsealed written contract that modifies a previous contract under seal. N. Y. Crv. Prac. ACT $\$ 342$.

8 Pa. STAT. (Purdon, I936) tit. $33, \S 6$. 


\section{ThIRD-PARTY BENEFICIARTES}

There has been rapid development of the law with respect to contracts for the benefit of third persons, all of it in the direction of recognition that such third persons have enforceable rights under the contract. Fifty years ago, there was strong criticism of such a doctrine, especially in cases where the third person is a creditor of the promisee and the contract is an undertaking by a promisor to discharge the duty owed by the promisee to such creditor. In New York the right of such a creditor had been enforced in the leading case of Lawrence $v$. Fox, ${ }^{9}$ the reasoning of the judges being not altogether harmonious. In several subsequent cases, the New York court attempted to narrow the application of the rule to facts exactly parallel to those in Lazorence $v$. Fox, declaring that no contract for the benefit of a third person is enforceable unless the performance promised will discharge "a legal or equitable duty" owed by the promisee to the third person. Such a limitation denies a right to a donee beneficiary; it could not fail to give serious dissatisfaction. The New York Court of Appeals has rendered numerous decisions in substantial conflict with it, and has all but repudiated it in express words. ${ }^{10}$ A rule that would deny an enforceable right to most beneficiaries of life insurance policies could not long prevail.

In several states the courts continued to say that "privity" of contract was necessary for enforcement, either in all cases, or in specified classes of cases, or in creditor beneficiary cases as opposed to those in which the beneficiary was a donee. Michigan denied the right in all cases; and then came the "hard cases" that began to make good law - at least, new law. ${ }^{11}$ The court

920 N. Y. 268 (x859).

to See especially Buchanan v. Tilden, I58 N. Y. Iog, 52 N. E. 724 (I899); Seaver v. Ransom, 224 N. Y. 233, 120 N. E. 639 (Igr8); Morgan v. Sanborn, 225 N. Y. 454, I22 N. E. 696 (xgrg); Croker v. New York Trust Co., 245 N. Y. I7, I56 N. E. 8I (I927) ; McClare v. Massachusetts Bonding \& Ins. Co., 266 N. Y. 37 I, I95 N. E. I5 (I935).

11 See the following cases: Preston v. Preston, 205 Mich. 646, I72 N. W. $37 \mathrm{I}$ (I9r9), aff'd on rehearing, 207 Mich. 68I, I75 N. W. 266 (I9x9); Bassett v. American Baptist Pub. Society, 215 Mich. 126, I83 N. W. 747 (I921); Clark Memorial Masonic Ass'n v. Colman's Estate, 222 Mich. 599, I93 N. W. 219 (r923) ; Jones v. Ireland, 225 Mich. 467 , I96 N. W. 369 (I923); Smith v. Thompson, 250 Mich. 302,230 N. W. I56 (I930). 
finally decided that the donee beneficiary of a contract can maintain a "bill in equity" to enforce it. It seems probable that it will before long reach the same result in creditor beneficiary cases, even though recent cases have held that such a beneficiary cannot maintain an action " at law".12

To hold that a third party has an enforceable right " in equity", even though he has not " at law", is to win the whole battle, so far as the substantive law of rights and duties is concerned. The plaintiff's juristic right against the promisor is recognized and enforced, without requiring any "privity". But the plaintiff's lawyer must make sure that he uses the equitable terminology and follows the proper procedure.

Massachusetts, Connecticut, and Pennsylvania have also been supposed to deny rights to the third person, with a less degree of truth than in the case of Michigan. Massachusetts is able to find an artificial "privity"; ${ }^{13}$ and it has also recognized enforceable rights "in equity". ${ }^{14}$ Connecticut early allowed a donee beneficiary to maintain suit at law. Next it held that a creditor beneficiary had a right in equity; and finally the uniform civil action under the code seems to be fully available to him. ${ }^{15}$ Pennsylvania consistently maintained two inconsistent lines of decisions, for more than one hundred years. ${ }^{16}$ It is unsafe to say that this inconsistency has as yet been wholly eradicated. The history that gets written into law reports remains there, ready to influence (I936).

12 E.g., George Realty Co. v. Gulf Ref. Co., 275 Mich. 442, 266 N. W. 4II

13 Gardner v. Denison, 2I7 Mass. 492, I05 N. E. 359 (1914).

14 Forbes v. Thorpe, 209 Mass. 570, 95 N. E. 955 (I9II). In Grime v. Borden, I66 Mass. I98, 44 N. E. 216 (I896), and Boyden v. Hill, I98 Mass. 477,85 N. E. 4I3 (I908), the court made use of the theory that the promisee had contracted as the "trustee" or "agent" of the third person. In a recent decision, the court has denied recovery to the beneficiary of a nonstatutory surety bond. Central Supply Co. v. United States Fid. \& Guar. Co., 273 Mass. 139, I73 N. E. 697 (I930). But there is a statute creating rights in laborers and materialmen on a public contractor's surety bond. MASs. GeN. LAws (I932) c. $30, \S 39$. Of course, the beneficiaries of life insurance policies are not denied a remedy.

15 Baurer v. Devenis, 99 Conn. 203, I2I Atl. 566 (I923); Byram Lumber \& Supply Co. v. Page, rog Conn. 256, I46 Atl. 293 (I929) ; Schneider v. Ferrigno, Iro Conn. 86, I47 Atl. 303 (1929); Tarcyak v. Bakasis, I82 Atl. 406 (Conn. 1936); see Corbin, Contracts for the Benefit of Third Persons in Connecticut (I922) 3 I YaLe L. J. 489.

16 The two lines of cases are reviewed by Corbin, Third Party Beneficiaries in Pennsylvania (1928) 77 U. OF PA. L. Rev. I, I6. 
the future, in spite of attempts at modification, either judicial or legislative, and even in spite of a dogmatic "overruling". In several recent cases, the Pennsylvania court has given judgment in favor of third persons, influenced by the general stream of decisions elsewhere and by the American Law Institute "Restatement". ${ }^{17}$

The Institute has flatly taken a position in favor of beneficiaries, both creditor and donee. ${ }^{18}$ This action is thoroughly justified by the flood of decisions; and it should have the effect of eliminating such conflict as still remains, along with much of the confusion in reasoning that plagues our legal system and immensely increases the amount and the cost of litigation. Consider the amount of litigation on contractors' surety bonds alone, bonds in which a surety makes an express promise to an owner that a building contractor will pay his laborers and materialmen. Several of the recent Pennsylvania cases are of this sort; and they gave judgment to the beneficiaries, ${ }^{19}$ in disregard of previous decisions to the contrary. The great majority of decisions elsewhere are also in favor of the beneficiary. ${ }^{20}$ Yet the surety companies continue to fight these cases through the courts of last resort; and the cost to the community of finding out what is "the law" is tremendous. It is in cases like this that the work of the Institute, if properly done, ought to have the effect of simplifying the administration of justice and making it less costly.

Of course, formal Restatements cannot avoid the litigation that turns on the question of interpretation of the variable words in surety bonds and other contracts. 'But builders' bonds have been in large measure standardized; and much of the constant litigation

17 Portland Sand \& Gravel Co. v. Globe Indemnity Co., 30r Pa. I32, I5I Atl. 687 (I930); Washington Steel Form Co. v. North City Trust Co., $308 \mathrm{~Pa} .35$, I62 Atl. 829 (I932); Concrete Products Co. v. United States Fid. \& Guar. Co., 310 Pa. I58, I65 Atl. 492 (I933); Commonwealth v. Great American Indemnity Co., 3I2 Pa. 183, I67 Atl. 793 (I933).

18 See Restatenient, Contracts (r932) §§ I33-47.

19 Washington Steel Form Co. v. North City Trust Co., 308 Pa. 35r, I62 Atl. 829 (I933); Concrete Products Co. v. United States Fid. \& Guar. Co., 310 Pa. I58, I65 Atl. 492 (1933); Commonwealth v. Great American Indemnity Co., 312 Pa. 183,167 Atl. 793 (1933).

${ }^{20}$ See Corbin, Third Parties as Beneficiaries of Contractors' Surety Bonds (I928) 38 YALE L. J. I; Campbell, Protection of Laborers and Materialmen under Construction Bonds (I935-36) 3 U. oF CEI. L. REv. I, 20 . 
has been over the legal operation of identical promissory language. The Institute did not see fit to draft a rule that is specifically applicable to these surety bonds, although such a bond that contains an express promise to pay claims ought to be held to be within the spirit and meaning of the Institute's general rules.

The laborers and materialmen are not exactly "creditors" of the promisee (the owner), although in many cases they have a lien on his property. They are creditors of a fourth party, the building contractor. These bonds are contracts in which $A$ promises $B$ to pay a debt that $C$ owes to $D$. Under a rule that enables $D$ to get judgment against $A$, we may regard $D$ as both a creditor and a donee; he is an intended donee of the security created by having an enforceable right against $A$, although he is not a donee of the money when $A$ pays it. Also, he is a creditor of $C$ in all cases; and in many cases he can collect his debt by enforcing a lien against the property of $B$, although he cannot get a personal judgment.

Judges and writers have at various times tried to justify the giving of judgment to third-party beneficiaries on artificial theories of subrogation, of agency, or of trusts, and to limit recovery to those cases in which the chosen theory is clearly applicable. ${ }^{21}$ In many cases, it is the plainest fiction to say that the facts of the case are included within the category to which these theories have previously been applied. Doubtless, it is often by bare-faced fiction that the law changes and develops, to the benefit of the community; the case under discussion is an excellent example of such development. But there always comes a time when the fiction should be recognized for what it is - a mere temporary expedient; the social policy that induced the invention of the fiction should be given more direct expression; and the limits of application of the rule should be determined by such social policy and not by the peculiar nature of the fiction. The Institute, while not attempting to state any social policy as a reason for its rules,

21 Subrogation theory: Keller v. Ashford, 133 U. S. 61o (x89o); Tamiami Inv: Co. v. Berk, 57 F.(2d) I034 (C. C. A. 3d, 1932) (good dissent); McIlvane v. Big Stony Lumber Co., I05 Va. 6I3, 54 S. E. 473 (I906) (a Virginia statute then gave a "direct" right only to sole beneficiaries); see Whittier, Contract Beneficiaries (I923) 32 Y ALE L. J. 790

Trustee theory: The use of this theory by the English courts is reviewed at length by Corbin, Contracts for the Benefit of Third Persons (1930) 46 L. Q. REv. x2. 
clearly recognizes that the rules that it states are not dependent on theories of subrogation, of agency, or of trusts. Likewise it purports to state rules of general law, not rules of " common law", or of " equity", or of " admiralty", or of the church.

If the Restatement has the influence that has been hoped for it, and that in the present instance it seems to be havirig, it should greatly reduce litigation by wholly eliminating the question of "privity" and the supposed requirement that consideration must move " from the promisee". There is plenty of cause for litigation remaining in the matter of interpretation of the varying words used by contractors and in answering the question whether the plaintiff is in fact a beneficiary within the ambit of the stated rules. Such continuing litigation will, as a matter of course, slowly impinge upon the form and content of the rules themselves, eventually requiring new critical research by scholars and new Restatements by new Institutes.

The requirement as to "privity" and the development of the law as to contracts for the benefit of third persons have followed the same devious and often inconsistent course in the Supreme Court of the United States as in the state courts. At various stages, that Court has recognized the right of the third person without discussion; ${ }^{22}$ has asserted that the third person has an enforceable right only when he is sole beneficiary; ${ }^{23}$ has based a creditor beneficiary's right on the doctrine of subrogation; ${ }^{24}$ has said that the third party's right created by a statutory surety bond is enforceable both in equity and at law; ${ }^{25}$ and very recently, in a suit by a materialman on a contractor's surety bond given as required by a state statute, the Court has said: "[the surety] contracts directly with the sub-contractor to assure the satisfaction of his just claims against the principal contractor. The remedy for a breach of this undertaking is an action at law." ${ }^{26}$ The Court then held in this recent case that the right of the materialman is a

22 Newell v. Nixon, 4 Wall. 572 (U. S. I866); Hendrick v. Lindsay, 93 U. S. $I 43(1876)$.

23 National Bank v. Grand Lodge, 98 U. S. I23 ( 1878 ).

24 Keller v. Ashford, I33 U. S. 610 (I890).

25 Mlinois Surety Co. v. United States, 240 U. S. 2I4 (I9I6). And see Johns v. Wilson, 180 U. S. 440 (Igor), enforcing a mortgagee beneficiary's claim by applying the law of Arizona.

${ }^{26}$ International Steel \& Iron Co. v. National Surety Co., 297 U. S. $65 \%, 664$ (I936). 
contract right that is protected by the Constitution against impairment by state legislation. There should be no quarrel with this decision. The third party's right is a contract right even though the contract that created it was not made with him. The materialman was a " third party", not a promisee; but the contract that created his right was protected against impairment, so that his right, as well as that of the promisee, was protected.

\section{ASSIGNMENT OF RIGHTS}

In other divisions of the law of contracts, there have been changes in mode of analysis and in forms of expression without any serious change in results actually reached. Thus, we may now say that a contract right or other " chose in action" is assign: able, whereas it was formerly said to be nonassignable " at common law". Whatever justification there may have been for the statement formerly made, the results actually reached by the courts and the business practices affected thereby have not been substantially changed. We are not now concerned with the exact character of the changes that resulted from the joinder of law and equity or from the adoption of new codes of procedure. It is merely asserted that the ultimate juristic effect of an assignment of a contract right has not been substantially changed even though the procedure by which that effect is determined and the courts to which it may be necessary to go have been much varied. The statement of existing law, as now made by the American Law Institute, could have been correctly made more than fifty years ago.

As an example of the foregoing, we may consider the case of a partial assignment. The right created in the assignee by such an assignment was once enforceable in "equity" only, the purpose of this limitation being the prevention of a multiplicity of separate suits by a number of partial assignees. This desired end is equally well attained in any modern court whose procedure is as flexible as was that of the court of Chancery. The Institute declares that the assignment of a fractional part is operative as to that part to the same extent as is the assignment of an entire claim. ${ }^{27}$ This purports to be a statement of general law, and 
there is no warning that it is not applicable in New Jersey, Tennessee, or other states maintaining a separate court of Chancery. Of course, it is quite possible that this statement may not be true, just as is the case with any other stated doctrine of the Institute or of any single jurist working and writing in his separate cloister. But the present writer will defend the statement.

Again, the Institute says that " rights under a bilateral contract can be assigned as effectively as rights under a unilateral contract ", a statement that seems to be in conflict with the stated rules of former treatises and judicial opinions. ${ }^{29}$ This seeming change is due only to a better analysis of jural relations. Under the " restated " rule no more than under former ones can a party get rid of his contractual duty by an attempted assignment or delegation. Further, if his contractual right to some performance by the other party is conditional in any manner, he cannot by an assignment make it unconditional; if his right is conditional upon his own personal rendition of a return performance, the right of his assignee will be subject to that identical condition.

By asserting that no substantial change in the law has been made by the new wording of the rule, it is not meant to assert that the new wording may not affect some actual decisions. The courts were likely to be misled by the older forms of statement; but the truth is that in spite of those forms the courts in general actually reached the results that are reached under the new form. If this is not true, the Institute was in error in adopting the new form.

\section{Impossibility of Performance}

What has been said about assignment is also true of other parts of contract law. Thus we once said that a person is not discharged from his contractual duty by the fact that its performance has since become impossible. ${ }^{30}$ But the concept of "impossi-

${ }^{28}$ Restatearent, Contracts (I932) § I6I.

29 Thus, Sir Frederick Pollock wrote: ". . . rights arising out of contract cannot be transferred if they are coupled with liabilities ...." PoxIock, Contracts (4th ed. 1888) 425. This statement was quoted with approval in Arkansas Valley Smelting Co. v. Belden Mining Co., I27 U. S. 379 (I888). Substantially similar statements are to be found in other treatises and opinions.

30 See the dictum in Paradine v. Jane, Aleyn 26, 27 ( 1647 ), repeated literally in many a modern treatise and court opinion. For the contradictory rule, see RestateMent, Contracts (1932) §457. 
bility" has been submitted to further analysis, and more consideration has been given to what it is that has become impossible. This was required by the fact that new cases arose in which the strict application of the rule as formerly expressed would give dissatisfaction, the new analysis and the new wording ("restatement ") being thus induced. This is, indeed, a development of law and a change in expressed rules, an extremely important matter. It seldom involves a conflict in actual decision. In the case of a contract that promised the delivery of possession of a specific building, the destruction of that building by fire was held to discharge the promisor's duty, even when the rule as formerly stated was not directly criticized..$^{31}$ How easy it was to make the decision turn upon the presumed intention of the parties! By a process of " interpretation", the promise was found to be conditional on the continued existence of the building, a result reached without introducing evidence as to the exact words of the parties and in spite of a high probability that the possibility of fire never entered their minds.

By processes like this, "impossibility" becomes a defense and an excuse from duty, in spite of statements that it is not. A clear and accurate statement of the results now reached by the courts requires many more sentences and paragraphs than were required in earlier times. Earlier broad generalizations must be reformed and reworded. Such expansion and development as this is not identical with that which involves a right-about-face, in action as well as in words, and the contrary decision of an identical issue. In all branches of the law, the former development is much more frequent than the latter; but both require the constant overhauling of our legal system and the constant restatement of all of those variable "working rules" of which any legal system is composed.

In dealing with the concept of impossibility, just as in dealing with the more inclusive concept of conditions precedent to a duty of immediate performance, the courts have given increasing consideration to the extent of the risk that a promisor should be regarded as having undertaken. In the performance of a contract, risks are encountered that the parties did not foresee or provide for. The court must then supply the gap and allocate 
the risks in accordance with reason - that is, in accordance with custom, business practice, common feeling, the mores of the community. Often, these are not so plain that he who runs may read; the court must be advised by evidence as well as argument.

This process is often inaccurately described as "interpretation" of the contract; it is less misleading to describe it as the "construction " of the contract, meaning thereby the determination by the court of the legal operation of the contract along with that of the facts that have occurred since its formation. The "intention of the parties ", as objectively expressed, is indeed an important and frequently the decisive element; but an intelligent judge is aware that his function goes far beyond the ascertainment of such intention.

The risk of objective impossibility, physical or legal in character, is now seldom made to rest upon a promisor; and there is a tendency to include under that head the occurrence of unexpected circumstances involving extraordinary difficulty or expense. The matter is one of degree; and the lines of risk allocation must be determined by the courts as they write the mores into law in the litigated cases that arise. The risk of mere personal and subjective inability to perform a promise must still be borne by the promisor, except so far as bankruptcy laws modify this risk and afford limited relief by throwing it in part upon the promisee.

\section{ACCORD AND SATISFaction}

Another illustration of this kind of development and restatement is found in the law of accord and satisfaction. "Upon an accord no remedy lies." So said Lord Chief Justice Eyre in I794. ${ }^{32}$ But the Contracts Restatement declares the exact contrary and indicates the several remedies that are available to both creditor and debtor. ${ }^{33}$ The new rules stated by the Institute are contrary to the actual decisions of very few cases in the last several centuries. Seeing a good contract that ought to be enforced, the courts easily reached the desired result by calling the executory agreement something other than "accord". This

32 Lynn v. Bruce, 2 H. Bla. 3 I7, 3 I8 (Ex. I794). This rule is repeated in (rgr4)

I C. J. 533-34, § 23 ; and again in (r936) r C. J. S. $543, \S 38$.

33 See $\$ 4$ I $\%$. 
process muddles up the use of legal terms and their definitions; it throws the stated law into confusion and renders it difficult for a judge to apply and for a student to learn and understand. It necessitates new analysis, new definition, and a "Restatement".

A journey further back into the law of accord and satisfaction will expose the other type of development and change. An accord executory is in almost all cases a bilateral agreement: each party makes a promise of some future performance. In the earlier centuries of English law, bilateral agreements seem not to have been enforced in the King's courts. As long as they were not enforced, it was correct to say that " upon an accord no remedy lies", provided that the accord was a bilateral one. The recognition and enforcement of bilateral agreements represented a major variation in the actual decision of issues. So far as concerns accord and satisfaction, no such change as this has occurred in the last fifty years, or several hundred.

\section{Agreements to Suspend a Right of Action}

An interesting example of the halting and unsatisfactory manner in which law develops may be found in the cases dealing with promises by a creditor not to sue his debtor for some limited time. It is not doubted that such a promise may be an enforceable contract; the problem is as to the legal effect of such a contract upon the enforceability of the creditor's prior claim. The well-known case of Ford v. Beech ${ }^{34}$ raises this problem, along with certain others. The facts were as follows: William Beech was indebted to Ford on two notes amounting to $\mathfrak{E}_{340}$. After their maturity, it was agreed by Ford, William Beech, and one Alfred Beech, that Alfred should pay either the sum of $£ 200$ in trust for Elizabeth Beech or an annuity of $\mathfrak{f}_{2} 5$ per year in quarterly installments, and that the rights of Ford against William Beech should be suspended so long as Alfred punctually performed his promise to make such payments. Alfred performed his promise to pay the annuity, although Ford thought the contrary; and this performance by Alfred was pleaded as a defense in a suit by Ford on William's two notes. The Court of Queen's Bench held that the 
plea stated a good defense; but this judgment against Ford was reversed in the Exchequer Chamber.

The upper court appealed to the ancient rule that " the right to bring a personal action, once existing and by act of the party suspended for ever so short a time, is extinguished and discharged, and can never revive ". ${ }^{35}$ Since it was obvious that Ford had never expressed an intention to discharge the debt of William Beech until the promise of Alfred should be performed in full, the court held that there was no suspension and no defense on the notes. It said, however, that the " agreement may give the defendant [William] a claim to damages by reason of the plaintiff suing in breach of it ".36

Before the Exchequer Chamber rendered final judgment, William and Alfred Beech brought a bill in Chancery, asking for specific enforcement of Ford's promise of suspension. The ViceChancellor, after final judgment had been rendered, entered a decree against Ford for specific performance of his promise, enjoining him from enforcing execution against William Beech on condition that Alfred should pay $\mathfrak{E}_{200}$ to Elizabeth Beech, and ordering the cancellation of the notes after such payment. ${ }^{37}$

From these two decisions, it appears that the legal operation of the agreement in the Court of Exchequer was different from its operation in Chancery. What should be said to be its legal operation in the courts of the United States, especially in those jurisdictions where there has been such a joinder of common law and equity that there is only one system of courts acting in accordance with a uniform procedure? The American Law Institute answers this question by declaring that such an agreement "bars an action ... . during the agreed time "..38 This is an abandonment of the common-law rule that a right of action could not be suspended for an instant without suffering complete extinction. Such an agreement now does what the parties have declared that it should do.

The specific agreement in the foregoing case was made for the

35 II Q. B. at 867.

36 Id. at 866.

37 Beech v. Ford, 7 Hare 208 (Ch. 1848 ).

38 Restatement, Contracts (I932) $\S 405$, with specific reference also to $\S 4 \mathrm{r} 7$, stating the law of accord and satisfaction. 
benefit of four separate parties, their jural relations under modern law being as follows: (I) William Beech's duty of immediate payment of the two notes was terminated, there being substituted a duty of future payment conditional on Alfred's failure to keep his promise. (2) To Elizabeth Beech (or in trust for her) the sums promised by Alfred Beech were to be paid. (3) Ford himself obtained a new security in the promise of Alfred Beech to pay either $\mathfrak{E}_{200}$ or a continuing annuity of $\mathfrak{E}_{2} 5$ to Elizabeth in discharge of Ford's previous claim for $\mathfrak{1}_{340}$ against William Beech. The agreement was both a contract not to sue for a specified time and an accord executory providing for the future total discharge of an existing claim by a substituted performance to be rendered by a new party. (4) Alfred Beech obtained the object for which he contracted, viz., a right that Ford should not sue William. It is the promise of Ford that is beneficial to William and Alfred, although its performance is directly beneficial to William alone. It is the promise of Alfred that is beneficial to Elizabeth Beech and Ford, although its performance is directly beneficial to Elizabeth alone. It should be observed that the legal operation of a promise must first be determined before the promise, regarded apart from its performance, can be said to be beneficial to anybody.

William Beech is benefited, in that if he is sued by Ford on the notes, he has a good defense as long as there has been no breach by Alfred. A suit against him during this period would be dismissed, without prejudice to a subsequent suit after a failure of performance by Alfred. Further, full performance by Alfred of either alternative stated in the new agreement will completely terminate William's duty to Ford. These benefits accrue to William in spite of the fact that he gave no consideration for them; it is Alfred who is paying for them. If William is regarded as a promisee in the new agreement, Ford's promise not to sue on the notes being a promise made to both William and Alfred, then William is both a donee beneficiary and a promisee beneficiary. ${ }^{39}$ If William was not in fact a promisee, then he is a third-party (and donee) beneficiary. It seems not to have occurred to the Vice-Chancellor that the law of England "knows nothing of a jus quaesitum tertio aris-

39 Vice-Chancellor Wigram said, "although William was not a party to the agreement, it is admitted that it was made with his privity, and he has a distinct interest in seeking that it may be enforced." 7 Hare at 216 . 
ing by way of contract ".40 He had plenty of precedent for his assumption that the contrary was then sound law and equity in England; ${ }^{41}$ and there is no doubt that his decision is in accordance with the generally prevailing law in the United States. ${ }^{42}$

Elizabeth Beech is plainly a donee beneficiary of the performance promised by Alfred Beech; and as such she could maintain suit for the enforcement of the promise. The money was to be paid to her (or in trust for her). Ford and Alfred Beech, having made mutual promises to each other (a bilateral contract), of course have the usual rights and remedies that are created by such a contract.

The question might arise whether William Beech, in addition to his rights and privileges as against Ford, does not also get an enforceable right against Alfred that the latter shall perform his promise to Ford. Alfred's faithful performance is certainly of great value to William; and his breach of promise would injure William by at once renewing Ford's right of action on the notes. Nevertheless, it may be that the courts are not yet ready to hold that Alfred's promise was made "for the benefit of" William. Alfred has laid himself open to actions by Ford and Elizabeth; perhaps a third action would seem to be one too many.

It is perfectly clear that under modern procedure, just as formerly in equity, the entire transaction and the legal relations of all four parties can and should be adjudicated in a single suit (assuming the possibility of service of process). The modern court can do exactly what Vice-Chancellor Wigram did; and it can do it in a suit exactly like that brought by Ford against William Beech on

40 The quotation is from Lord Haldane's opinion in Dunlop Pneumatic Tyre Co. v. Selfridge \& Co., [I9I5] A. C. 847,853 .

41 The English cases are reviewed in Corbin, supra note $2 \mathrm{x}$. The case of Tweddle v. Atkinson, I B. \& S. 393 (Q. B. I86I), was still to come, and then at common law only.

42 That a third-party beneficiary can get, not only an enforceable right against a promisor, but also a legal privilege of not performing his former duty (i.e., a defense), is expressly recognized by the Law Institute, in $\S 405$, illustration I: "A owes $B$ a matured debt of $\$ 100$. $B$ assigns his right to $C$, receiving in return C's promise not to sue $A$ for one year. $C$ cannot maintain an action against A before the end of the year." This is on all fours with Baurer v. Devenis, 99 Conn. 203, 121 Atl. 566 (1923). The juristic rights and privileges of William should be regarded as being derived from both common law and equity, if the question of their derivation makes any difference under modern American law. 
the latter's two notes. William could plead his defense, and stop there if he so desired. Alfred could intervene voluntarily, or could be brought in against his will. Ford and Elizabeth could separately or jointly get a decree for specific performance against Alfred. Neither Alfred nor William would need an injunction against Ford, unless Ford is suing in another jurisdiction. Ford could get a decree enforcing Alfred's promise as an accord executory, or could get judgment against William for the amount of the notes if the court is unable (or is not asked) to make Alfred pay.

Does the foregoing demonstrate a development of the law of contracts? In the main, it indicates a development in the procedure of courts, but the recognition and enforcement of contract rights often depends directly upon an understanding of the changes that have occurred in courts and their procedure. The juristic operation of the agreement between Ford and Alfred Beech as recognized in the court of Chancery is now its juristic operation under our unified system of law in practically all of our courts. This is recognized in the doctrines adopted by the Law Institute. One of the beneficial functions of that body, of which it may not always be aware, and one which some of its critics may not have observed, is the open abandonment of old doctrines that for any reason have become obsolete or inaccurate, and the restatement of new ones as required by judicial decisions or by the reorganization of court systems and procedure.

Not all modern courts have clearly recognized the juristic implications of the foregoing development of court powers and procedure; it may be only a fraction of the bar who are sufficiently aware of it to render efficient service to their clients. This may be illustrated by the case of Reilly v. Barrett, ${ }^{43}$ not yet twenty years old.

The plaintiff in this case sued in a tort action for damages. The defendant denied the tort; and in a supplemental answer alleged that an agreement was made, whereby he promised to pay $\$ 200$ and the plaintiff promised to receive that sum in full satisfaction and that he had tendered payment of the money. The court sustained a demurrer to this supplemental answer. It should not have done so. As the court said, the agreement was an accord executory 
and not itself a satisfaction of the tort claim; but the court was in error when it said: "An accord, when followed by satisfaction, is a bar to the assertion of the original claim. Until so followed it has no effect." 44 The New York court was a statutory court, with both equity and common-law powers, with the duty of applying equity rules where they differ from the common law, and with a flexible procedure enabling it to recognize defenses and to give all forms of relief appropriate to the case. It should have held that the accord was a perfectly valid bilateral contract, operating as a suspension of the plaintiff's right of action and specifically enforceable in the very action that had been brought. The court should have overruled the demurrer; and later, in case the agreement and tender were proved, should have given judgment for the defendant, conditional on payment of $\$ 200$ into court. If the defendant argued that the agreement was itself a final discharge of the tort claim, he was in error; but this does not justify the court in sustaining the demurrer and proceeding with the enforcement of that claim. Apparently, the court still held the view that the agreement was not an enforceable contract, that " upon an accord no remedy lies".

\section{Changing Mores and Sanctity of Contract}

Some of the developments above described may be regarded as striking and important changes in the law of contracts. But they are neither so striking nor so important as are changes in the social mores that form the basis of all law and the ultimate source from which legal generalizations and judicial opinions are drawn. No attempt will here be made to enumerate and describe these changes in the social mores with any definiteness or certainty. A few suggestions may be attempted as to their character, as to their causes, and as to the particular parts of the stated law that they are likely to affect. Such changes cannot be enumerated and described without an experience in the lives and opinions of men and an extended research into myriads of transactions beyond the capacity of any writer. Assuredly, the present writer has made no such research and has had no such experience. 
Many persons believe, sometimes regretfully and sometimes with satisfaction, that in very recent times there has been a serious decline in respect for the obligation of contract and a growing conviction that the breaking of promises is socially just and right, when their performance or enforcement involves hardship or a substantially greater effort and sacrifice than was anticipated by the promisor when the contract was made. Has not our own Government effectually repudiated its solemnly attested promises to repay borrowed money in gold? Has it not, by enacted legislation, attempted to prevent the performance of similar promises by private individuals? Is not the breaking of national promises now generally regarded as justifiable international policy? Do the members of college faculties regard themselves as bound by a contract of service with the college? Are labor unions and the members of labor unions justified in striking for better wages and conditions in spite of a contract with their employer? Is the repudiation of a contract justified by the fact that one of the contractors had greater economic power than the other?

It may be that there has been less change in these matters than is commonly supposed. Such change as there has been is without doubt the result of the destruction of wealth, business depression, and economic hardship. It may well be that the depression and hardship will pass before there has been time to write the change in popular attitude into statutes and judicial opinions. But it is certain that the change will be so written, if the prevailing sentiment of the community continues to support it. There would thus result a change in contract law much more fundamental and farreaching than any of the changes in theories of mutual assent, consideration, or third-party beneficiaries. It does not necessarily follow that such a fundamental change would work well; instead, it might even accelerate the destruction of wealth and add to the general economic hardship that caused it.

It must be recognized that both popular mores and judicial decisions have long justified the nonperformance of many contracts for a variety of reasons. We have had discharge in bankruptcy without consent of creditors; and we have had contractual duties limited by the court under a flimsy disguise of "interpretation", when the court was really creating constructive conditions and excuses from duty on grounds of supposed social policy and " fair- 
ness ". If there has been new relaxation in the theory of sanctity of contract, the difference is merely one of degree. The pendulum has merely swung farther to the left before it makes its necessary return movement to the right.

\section{Changing Mores and Liberty of Contract}

This article does not undertake to state all the changes or to indicate all the major developments in the law of contracts during the past fifty years. Changes started within that period are still in progress; and their results are as yet impossible of dogmatic restatement. With respect to "illegal bargains", where is now the line separating the lawful from the unlawful, particularly in the field of contracts in restraint of trade? Old doctrines have suffered from the impacts of war, depression, and legislation. The NIRA has left scars, even though declared unconstitutional. It revived old practices and started new ones. New notions as to what makes for the general welfare have made headway; their soundness is still in process of testing and their survival is in the balance. It will be for the courts to amalgamate what is good in the new with what remains of the old; and it can hardly be supposed that this will not compel some restatement of the law in matters of importance.

The evolution of law proceeds by a constant struggle, between individuals or groups of individuals, for rights and privileges; that is, for the aid of the social organization against others and for its forbearance from interference against ourselves, for protection and for liberty. Each would like to have utter freedom of competition for himself - unlimited privileges of procuring the satisfaction of his own desires; and at the same time each desires extensive limitations on the freedom of competition by others for the objects of desire. "Law" is the resultant of this struggle. We are compelled to barter away some privileges in order to gain some rights; and human action is thereby divided into the "lawful" and the "unlawful ", the permitted and the forbidden.

It is in this setting that the concept of "liberty of contract" must be examined. Each one would like to be free to make such bargains as he pleases; but he must surrender a part of that freedom if he desires that others should surrender a part of theirs. 
Thus the making of certain bargains becomes unlawful - forbidden. Again, each one would like to have the aid of society in the enforcement of such bargains as he pleases to make; but he is not willing that others should have such aid in the enforcement of all of their bargains. Therefore, he must be content that certain bargains shall give him no rights in order that others also shall have none.

Since the evolution of law is struggle and compromise, no system of law can ever be static or definitely knowable. The law is not " a brooding omnipresence in the sky". Therefore, the lines that separate lawful bargains from the unlawful, the lines that separate criminal bargains from those that are only tortious, as well as from those that are only unenforceable, are always blurred and variable. There are no lines, but only zones with fringes. The struggle is a continuing struggle; the compromise is constantly renewed. Legislatures as well as courts constantly take a hand in constructing new lines and distinctions. The practices of business, and even the fundamental mores that are the source of our notions of "right and wrong" are in constant process of evolution. Our beliefs as to what general welfare and "public policy" require are confused and inharmonious. ${ }^{45}$

Arthur L. Corbin.

YaLE Schoor of Law.

45 The preceding three paragraphs are in large part taken from an introductory note to Chapter 12 of the present writer's CaSES ON THE LAW OF ConTRACTS (2d ed. I933), copyrighted by the West Publishing Company. It should be perfectly obvious that in these paragraphs the writer is not discussing the question of constitutional power of courts or legislatures to deprive individuals of the privilege of making contracts or of their power to make enforceable ones. It is here the underlying assumption, justified by the long history of the common law, that such power exists in both courts and legislatures. There may, of course, be constitutional limits on that power; but this paper is not a commentary on progress in constitutional interpretation or in political theory. See Pound, Liberty of Contract (Ig09.) I8 YALE L. J. 454. 